\title{
Darba tiesisko attiecību izbeigšanas problemātika Darba likuma 101. panta pirmās daḷas 3. un 4. punktā noteiktajos gadijjumos
}

\author{
Dace Tarasova \\ Rīgas Stradiña universitāte, Juridiskā fakultāte, Latvija \\ tarasova.dace@gmail.com
}

\section{Kopsavilkums}

Saskan̄ā ar Latvijas Republikas Satversmes 106. pantu ikvienam ir tiesības brīvi izvēlēties nodarbošanos un darbvietu atbilstoši savām spējām un kvalifikācijai. Piespiedu darbs ir aizliegts. Par piespiedu darbu netiek uzskatīta iesaistī̌sana katastrofu un to seku likvidēšanā un nodarbināšana saskaṇā ar tiesas nolēmumu [11].

Rakstā tiek aplūkots darba tiesisko attiecību izbeigšanas tiesiskais regulējums. Tiek analizēts arī darba devēja uzteikums, kas praksē bieži vien tiek pārsūdzēts tiesas ceḷā, kā liecina Tiesu informācijas sistēmas statistiskie dati, proti, 2016. gadā līdz 25. oktobrim tika iesniegtas 68 prasības par atjaunošanu darbvietā, savukārt 2015. gadā - 88 prasības [16]. Šie dati, pēc autores domām, norāda uz vairākām problēmām Latvijas darba tiesību jomā, konkrēti - darba tiesisko attiecību regulējumā. Tiesu informācijas statistikas dati neatklāj prasību saturu, taču liecina par problēmas aktualitāti. Autore uzskata, ka darba tiesisko attiecỉbu izbeigšanu var pētīt, pamatojoties uz to, ka darbinieks, veicot darbu, rīkojies pretēji labiem tikumiem, un šāda rīcība nav savienojama ar darba tiesisko attiecību turpināšanu, un ja darbinieks, veicot darbu, atradies alkohola, narkotiku vai toksiska reibuma stāvoklī.

Raksta mērḳis ir konstatēt darba tiesisko attiecību izbeigšanas problēmas, kas pastāv atbilstoši Darba likuma 101. panta pirmās daḷas 3. un 4. punktam, un izstrādāt priekšlikumus šo problēmu novēršanai.

Materiāls un metodes - normatīvo aktu, tiesu prakses un zinātniskās literatūras analīze un apraksts. Iegūtie rezultāti tika novērtēti, izmantojot aprakstošo, analītisko, logisko, indukcijas un dedukcijas, logiski konstruktīvo metodi, savukārt tiesību normu interpretācijai tika izmantota gramatiskā, sistēmiskā un teleologiskā tiesību normu interpretācijas metode.

Atslēgvārdi: darba tiesiskās attiecības, uzteikums, darba strīdi, Darba likums. 
Darba tiesisko attiecību priekšmets ir darbs, kas tiek skaidrots arī kā amata pienākumi, to veikšana, tajā skaitā arī ieņemamais amats [6]. Pienākums, uzdevums - tas, kas jāpadara [6]. Darbs ir arī cilvēka mērḳtiecīga darbība, lai radītu materiālas vai garīgas vērtības, sniegtu pakalpojumus, kas nepieciešami sabiedrības vajadzību apmierināšanai [13]. Tādēl darbiniekam, veicot darbu, ir jārīkojas atbilstoši labiem tikumiem, t. i., nedrīkst veikt darbu alkohola, narkotiku vai toksiska reibuma stāvoklī.

Izbeigt darba tiesiskās attiecības var vairākos veidos ar uzteikuma institūta palīdzību. Darba tiesisko attiecību izbeigšana Darba likumā ir cieši saistīta, ar jēdzienu "uzteikums", kas likumā tiek lietots ar dažādām nozīmēm. No teorētiskā viedokḷa darba līguma uzteikums ir darbinieka vai darba devēja izteikts vienpusējs rakstisks gribas izteikums, ar kuru tiek izbeigtas darba tiesiskās attiecības uz turpmāku laiku [9]. Tātad uzteikums ir dokuments, kurā ir norādīts pamatojums, izbeidzot darba tiesiskās attiecības, un tas ir pierādījums, iesniedzot tiesā prasību, ja ir aizskartas darbinieka tiesības un ja darba devējs nav pilnīgi veicis savus ar Darba likumu noteiktos pienākumus. Autore vērš uzmanību uz to, ka pēc būtības uzteikuma pamatojums ir nepieciešams darba devējam, jo tas noteikts Darba likuma normās.

Darba likuma 26. un 28. nodaḷā ir paredzēti vairāki darba tiesisko attiecību izbeigšanas pamatojumi:

1) darbinieka uzteikums;

2) darba devēja uzteikums, kura iemesli noteikti Darba likuma 101. pantā, kā arī 98. pantā minētais gadījums (darba devēja uzteikums piedāvāto darba līguma grozījumu dēl);

3) uz noteiktu laiku noslēgtā darba līguma izbeigšanās;

4) darbinieka un darba devēja vienošanās;

5) trešo personu pieprasijums un tiesas spriedums;

6) darba devēja nāve;

7) uzteikums pārbaudes laikā [5].

Darba likuma 101. panta pirmās daḷas 3. punktā kā viens no darba devēja uzteikuma pamatiem ir noteikts gadījums, ka darbinieks, veicot darbu, rīkojies pretēji labiem tikumiem, un šãda rīcība nav savienojama ar darba tiesisko attiecību turpināšanu [5]. Lai uzteiktu darba līgumu, pamatojoties uz šo Darba likuma normu, jāpastāv vairākiem priekšnoteikumiem, proti, darbinieka rīcībai, kas ir pretēja labiem tikumiem, šādas rīcības nesavienojamībai ar darba tiesisko attiecību turpināšanu, kā arī šādai darbinieka rīcībai jābūt saistìtai ar darbinieka veicamo darbu. Pēdējais no priekšnoteikumiem attiecas gan uz tiem gadījumiem, ka darbinieks veic darbu viņam noteiktajā darba laikā, gan uz tām situācijām, ka darbinieks veic ar darbu saistītus pienākumus pēc viṇam noteiktā darba laika. Saskaņā ar Darba likuma 130. panta pirmo dalı u ar darba laiku ir jāsaprot laikposms no darba sākuma līdz beigām, kura ietvaros darbinieks veic darbu un atrodas darba devēja rīcībā, iznememot pārtraukumus darbā, līdz ar to darbinieks ir darba devēja rīcībā neatkarīgi no darbinieka atrašanās vietas [5]. 
Augstākās tiesas Senāts par Darba likuma 101. panta pirmās daḷas 3. punktā minēto uzteikuma pamatu ir paudis viedokli, ka uzteikuma pamatojums var būt darbinieka tāda rīcība, kas saistīta ar darba pienākumu izpildi, turklāt darba devējam ir jāpamato, ka darbinieka konkrētā rīcība liedz turpināt darba tiesiskās attiecības [12].

Jèdziena "labi tikumi" saturs normatìvajos aktos nav noteikts, un ar to palīdzỉbu tas nav atklājams. Saskaṇā ar tiesību teoriju, šis ir atzīstams par atklātu jeb nenoteiktu jēdzienu, kas dod tikai aptuvenu priekšstatu par iespējamo virzienu, kur meklējams konkrētā jēdziena saturs [14]. Jēdzieni "labs", "tikums" ir saistāmi ar cilvēka apzinu, rīcības novērtējumu, tāpēc tie attiecināmi uz ètikas un morāles normām, taču nedrīkst aizmirst par subjektīvo novērtējumu, kas gandrīz vienmēr atškiras atkarībā no personas uzskatiem, izglìīibas u. c. faktoriem. Tāpēc autore šaubās, ka tiks nodrošināta darbinieka aizsardzība, ja darba devējs darba tiesiskās attiecības izbeigs, pamatojoties uz Darba likuma 101. panta pirmās daḷas 3. punktu.

N̦emot vērā, ka likumdevējs nav noteicis "labu tikumu" definīciju, šis jēdziens īpaši kvalificētās nenoteiktības pakāpes dēḷ ir atzìts par generālklauzulu, kuras saturu veido mainīgā sabiedrības vērtību sistēma un kuras konkretizēšana jāveic tiesu praksei. Mūsdienu tiesu praksē un tiesību zinātnē ir atzîts, ka labu tikumu jēdzienam ir ne tikai sociāls, bet arī tiesisks raksturs, proti, to veido ne tikai vispārpien,emtās morāles normas, kas noteic savstarpējās uzvedības noteikumus, kurus sabiedrība vai kāda tās daḷa atzīst par nepieciešamu ievērot, bet veido arī tiesiski ētiskie principi un vērtības, kas nostiprinātas pozitīvajās tiesībās, tostarp - valstu konstitūcijās [15]. Tādējādi jēdziens "labi tikumi" ir generālklauzula, kuras aizpildīšana ar saturu ir atstāta tiesību piemērotāju ziṇā [12].

Senāta ieskatā, Civillietu tiesas kolēgijia pamatoti kvalificējusi kā rīcību pretēju labiem tikumiem Darba likuma 101. panta pirmās dal̦as 3. punkta izpratnē situāciju, ka darbinieks darba devēja organizētā un samaksātā pasākumā, veicot pārrunas ar uzṇēmumam svarīgiem klientiem, bija tādā alkohola reibumā, kas apkauno prasītāju personīgi, kā arī būtiski kaitē darba devēja reputācijai, turklāt darbinieka uzvedība ir apdraudējusi citu cilvēku veselību un dzīvību. Šāda rīcība nav savienojama ar darba tiesisko attiecību turpināšanu, jo darba devējs nevar paḷauties, ka darbinieks, pildot amata pienākumus, turpmāk rīkosies atbilstoši sabiedrībā vispārpieņemtām ētikas un morāles normām. Veicot darba pienākumus darba devēja apmaksātā klientu pasākumā, darbinieks pārstāv un iepazīstina ar darba devēju [15]. Tādēl var secināt, ka arī alkohola, narkotiku vai toksiska reibuma stāvoklis, veicot darbu neatkarīgi no darba pienākumu izpildes vietas, ir pielīdzināms rīcībai, kas ir pretēja labiem tikumiem. Turklāt, pēc autores domām, pretēja labiem tikumiem ir arī amorāla uzvedība un / vai rīcība, kas mūsdienās ir plašs jēdziens, proti, darbinieks rīkojas netikumiski, pretēji morāles principiem. Problēma rodas noteikt, kādu darbỉbu vai bezdarbību var uzskatìt par amorālu uzvedību un / vai rīcību. Autore uzskata, ka vērtējums par darbinieka amorālu uzvedību vai rīcību var tikt piemērots profesijās, kuras ir saistītas ar audzināšanas funkciju izpildi, piemēram, pedagogiem.

Nemot vērā mūsdienu zinātnieka K. Torgāna pausto atziṇu, ka amorāls pārkāpums un rīcība pretēji labiem tikumiem nav nekas abstrakts un nav interpretējams pēc puses 
subjektīvajiem ieskatiem, autore secina, ka darbiniekam varētu uzteikt darba līgumu pēc analizējamā uzteikuma pamata, ja viña rīcība bijusi konkrēta un pierādīta [17]. Tādējādi, lai darba devējs varētu uzteikt darba līgumu, viṇam jāpierāda, ka darbinieks ir rīkojies pretēji labiem tikumiem un / vai šāda rīcība nav savienojama ar darba tiesisko attiecību turpināšanu.

Papildus iepriekš minētajam Darba likuma 101. panta pirmās dal̦as 3. punkts praksē piemērojams arī gadījumos, ja darbinieks rupji un netaktiski izturas pret uzñēmuma klientiem, kontaktēšanās laikā pieḷauj izturēšanos, kas grauj uzṇēmuma reputāciju, un šāds darbinieks var samazināt uzñēmumam klientu skaitu un kaitēt apgrozijumam un peḷnai. Šajā gadījumā darba devējam būtu pamats apgalvot, ka darbinieka netaktiskā izturēšanās nav savienojama ar darba tiesisko attiecību turpināšanu. Lai veicinātu Darba likuma 101. panta pirmās daḷas 3. punkta piemērošanu, darba devējam ir nepieciešams izstrādāt "labo tikumu" definīciju, kas jāietver iekšējos normatīvajos aktos. Jāṇem vērā, ka darbs pie katra darba devēja ir atšḳirīgs, un arī amata pienākumi atšḳiras, tādēl arī "labo tikumu" jēdziena izpratne dažādiem darba devējiem atšḳirsies. Piemēram, ir pašsaprotami, ka veikala uzṇēmumu darbinieki darba vietās atrodas gèrbušies darba drēbēs, bet nav pieṇemams, ja šādā apgēēbā darbā atrodas juridiskā biroja darbinieks.

Jāpiebilst, ka atsevišḳām profesijām ir izstrādāti ētikas kodeksi, piemēram, Latvijas zvērinātu advokātu ētikas kodekss, kas satur informāciju par profesijā strādājošajiem nepieciešamajiem tikumiem, kā arī tajā norādìti darbības principi, kā uzturamas attiecības ar klientiem u. tml. Domājams, ka darba devējam būtu iekšējos normatīvajos aktos konkrēti jānorāda kritēriji, kuri darbiniekiem reglamentētu uzvedības pamatnoteikumus uzṇēmumā, veicot darba pienākumus. Tie ḷautu darba devējam darba tiesisko attiecību izbeigšanas gadijumā saskañā ar Darba likuma 101. panta pirmās dalıas 3. punktu uzteikt darba tiesiskās attiecības ar darbinieku.

Darba likuma 101. panta pirmās daḷas 4. punkts attiecas uz darba tiesisko attiecību izbeigšanu, ja darbinieks, veicot darbu, atradies alkohola, narkotiku vai toksiska reibuma stāvoklī [5]. Alkohola reibuma stāvoklis ir viens no iemesliem darba tiesisko attiecību izbeigšanai. Tas ir tiesiski noteikts Darba likumā un ir saistīts ar darbinieka uzvedību. Darba devējam, izvērtējot pārkāpuma būtību, darbinieka uzvedību, attieksmi u. tml., ir tiesības, bet ne pienākums uzteikt šajā gadījumā darba līgumu [4]. Darba likuma 101. panta pirmajā dạ̄ā ir teikts, ka darba devējam ir tiesības rakstveidā uzteikt darba līgumu, vienīgi pamatojoties uz apstākḷiem, kas saistīti ar darbinieka uzvedību, viña spējām vai ar saimniecisku, organizatorisku, tehnolog̣isku vai līdzīga rakstura pasākumu veikšanu uzñēmumā [..] [5].

Pēc autores domām, Darba likuma 101. panta pirmās dal̦as 4. punktā lietotais jēdziens "reibums" nav pietiekami skaidrs. Reibums ir stāvoklis, kad zūd līdzsvara sajūta, skaidra uztveres un spriešanas spēja (parasti kādu vielu iedarbības dēl).

2014. gada 29. janvārī Ventspils tiesas spriedumā lietā Nr. C40141313 bija atsauce uz Augstākās tiesas 2012. gada 24. augusta spriedumu lietā Nr. SKC-1041/2012, norādot, ka, konstatējot pārbaudāmās personas ārējo izskatu, Augstākās tiesas Senāts 2012. gada 
24. augusta spriedumā lietā Nr. SKC-1041/2012 norādījis, ka darbinieka izelpā konstatētais alkohola daudzums 0,09 promiles neliecina nedz par viņa atrašanos alkohola ietekmes, nedz alkohola reibuma stāvoklī. Senāts atsaucas uz Ministru kabineta 2008. gada 2. jūnija noteikumu Nr. 394 28. punktu un uz Veselïbas inspekcijas skaidrojumu par to, kā atškiras alkohola reibums no alkohola ietekmes. Slēdziens "ir konstatēta alkohola ietekme" tiek dots gadījumos, ja alkohola koncentrācija pārbaudāmās personas asinīs pārsniedz 0,5 promiles (ieskaitot) vai tam atbilstoša koncentrācija citā biologiskā vidē ir orientējoši līdz 1,0 promilei, izvērtējot klīnisko simptomātiku, kas izpaužas kā nelieli kustību koordinācijas traucējumi, alkohola smaka no mutes, sklēru un sejas ādas hiperēmija, paātrināta elpošana un sirdsdarbība. Savukārt slēdziens "ir konstatēts alkohola reibums" tiek sniegts gadījumos, ja alkohola koncentrācija pārbaudāmās personas asinīs pārsniedz 1,0 promili (ieskaitot), ar klīnisko simptomātiku, kas izpaužas kā izteikti kustību koordinācijas traucējumi, nestabila gaita, garastāvokḷa nelīdzsvarotība, pavājināta mīmika u. tml. [18].

Jāpiebilst, ka šeit minētie Ministru kabineta noteikumi ir attiecināmi uz Valsts policijas, pašvaldïbas policijas, ostas policijas, Valsts robežsardzes darbinieka, Valsts agentūras "Civilās aviācijas aǵentūra" inspektora vai Valsts probācijas dienesta amatpersonas veiktu pārbaudi ar portatīvu mērierīci alkohola koncentrācijas noteikšanai izelpotajā gaisā, lai noskaidrotu, vai persona ir lietojusi alkoholu [2]. Šie noteikumi ir palīglīdzeklis, lai tiesībsargājošās instances amatpersonas varētu kontrolēt citu tiesību normu izpildi, piemēram, autotransporta vadīšanu alkohola, narkotiku vai toksiska reibuma stāvoklī, ar mērḳi sodīt likumpārkāpēju. Taču šie noteikumi neattiecas uz darba devēja un darbinieka darba tiesiskajām attiecībām.

Lai nepiel̦autu darbinieka atrašanos darba devēja telpās reibuma stāvoklī, iekšējos normatīvajos aktos vai darba līgumā nepieciešams ietvert aizliegumu lietot apreibinošas vielas darba devēja telpās arī ārpus darba laika un amata pienākumu pildīšanas, taču pārkāpums tik un tā būtu kvalificējams pēc Darba likuma 101. panta pirmās daḷas 1. punkta. Būtiski ir noteikt uzṇēmumā darbinieka reibuma pārbaudī̌sanas kārtību un reibuma piel̦aujamības pakāpi, n̦emot vērā veicamā darba specifisko raksturu.

Valsts darba inspekcijas Juridiskās nodaḷas vadìtājs skaidro, ka darba devējam šāds darbinieks jāatlaiž, strikti ievērojot vairākus noteikumus, proti, jābūt pierādījumiem, proti, faktam, ka darbinieks darbā strādājis alkohola reibumā, un jāievēro likumos noteiktā atlaišanas procedūra. Vadītājs arī atgādina, ka no darba nevar atbrīvot darbinieku, kura asinīs ārsti atraduši alkohola ietekmi, jo Darba likums piel̦auj atlaišanu no darba tikai alkohola reibuma gadijumos [8].

Autore uzskata, ka nolūkā novērst strīdus par reibuma esamību darba devējam darba līgumā vai citos darba devēja iekšējos normatīvajos aktos jāparedz darbinieka obligāts pienākums veikt reibuma pakāpes pārbaudi, ja darba devējam rodas aizdomas par atrašanos darba vietā reibuma stāvoklī. Minētā pienākuma neievērošana sniegtu darba devējam iespēju izbeigt darba tiesiskās attiecības ar šo darbinieku. Turklāt nepieciešams izstrādāt arī pārbaudes veikšanas kārtību. 
Autore uzskata, ka darba tiesiskajās attiecībās nebūtu korekti lietot terminu "reibumā", bet pareizāk būtu lietot "ietekmē", jo būtu aplami uzskatît, ka persona var atrasties narkotisko un toksisko vielu reibumā. Persona var būt narkotisko un toksisko vielu ietekmē, n,emot par pamatu Latvijas Administratīvo pārkāpumu kodeksa u. c. normas, piemēram, Latvijas Administratīvo pārkāpumu kodeksa 117.7 pantu: atpūtas kuguu vadīšana alkohola reibumā vai narkotisko, vai citu apreibinošo vielu ietekmē [1]. Vēl kāds šā jēdziena lietošanas piemērs atrodams Krimināllikuma normās, 262. pants: transportlīdzekḷa vadišsana alkohola, narkotisko, psihotropo, toksisko vai citu apreibinošu vielu ietekmē [10].

Savukārt Iekšlietu ministrijas sistēmas iestāžu un Ieslodzijjuma vietu pārvaldes amatpersonu ar speciālajām dienesta pakāpēm dienesta gaitas likuma 14. panta septìtajā daḷā ir noteikts šādi: ja ir aizdomas par to, ka amatpersona, pildot dienesta pienākumus, ir alkohola, narkotisko, psihotropo, toksisko vai citu apreibinošu vielu ietekmē vai reibumā, augstāka amatpersona to nogādā medicīniskās pārbaudes veikšanai [7].

Tādēḷ autore piedāvā izteikt Darba likuma 101. panta pirmās daḷas 4. punktu jaunā redakcijā: "[..] darbinieks, veicot darbu, ir alkohola, narkotiku vai toksisku vielu ietekmē vai reibumā." Pēc autores domām, šã panta 4. punkta jaunā redakcija nepiel̦autu atrašanos darbvietā, kā arī darba veikšanu - neatkarīgi no veicamā darba faktiskās vietas - darbiniekam esot alkohola, narkotisko un toksisko vielu ietekmē. Turklāt šāds labojums nepiel̦autu ierašanos darbvietā alkohola, narkotisko un toksisko vielu ietekmē, un rezultātā darba devējam būtu tiesības nepielaist darbinieku pie darba pienākumu pildǐšanas.

N̦emot vērā iepriekš minēto, jāpiebilst, ka Augstākā tiesa savā 2005. gada apkopojumā "Jautājumi par Darba likuma normu piemērošanu", būtībā apstiprina iepriekš pausto autores viedokli, proti, Darba likuma normas neparedz ìpašu fakta par darbinieka atrašanos alkohola, narkotiku vai toksiska reibuma stāvoklī pierādīšanas kārtību, tādēl atrašanos alkohola, narkotiku vai toksiska reibuma stāvoklī var konstatēt ar jebkuriem Civilprocesa likuma 17. nodal̦ā paredzētajiem pierādīšanas līdzekḷiem (ar paša darbinieka paskaidrojumu, ar attiecīga akta sastādīšanu, ar liecinieku liecībām, ar medicinas darbinieku atzinumu, ārstu ekspertīzes atzinumu u. tml.) [3].

Autore piekrīt, ka atrašanos reibumā būtu jākonstatē ar Civilprocesa likumā paredzētajiem pierādīšanas līdzekḷiem. Tādējādi nepieciešams Darba likuma 101. panta pirmās dal̦as 4. punktu izteikt šādā redakcijā: "[..] darbinieks, veicot darbu, ir alkohola, narkotiku vai toksiska reibuma stāvoklī. Šos apstākḷus darba devējs pierāda ar Civilprocesa likumā paredzētajiem pierādīšanas līdzekḷiem.” 


\section{Secinājumi}

1. Darba likuma 101. panta pirmās dạ̦as 3. punkts praksē piemērojams, ja darbinieks rupji un netaktiski izturas pret uznēemuma klientiem, komunikācijas laikā piel̦auj uzvedību, kas grauj uzṇēmuma reputāciju, un šìs darbinieka rīcības dēl samazinās uzñēmuma klientu skaits, tiek kaitēts uzṇēmuma apgrozỉjumam un pelnai.

2. Darba devējam būtu lietderīgi izstrādāt "labo tikumu" definīciju, ko ietvert iekšējos normatīvajos aktos. Papildus ir jāṇem vērā, ka darbs pie katra darba devēja ir atšḳirīgs un arī amata pienākumi atšḳiras, tādēl arī "labo tikumu" jēdziena izpratne dažādās darbvietās atšksirsies.

3. Labo tikumu definīcijas izstrāde būtu vērtējama kā ieguvums gan darba devējam, gan darbiniekam, jo ekonomēts tiktu laiks un naudas resursi, kā arī atvieglota tiesu noslodze.

4. Darba likuma 101. panta pirmās dạ̦as trešajā punktā minētais termins "veicot darbu" ierobežo darba devēja rīcības brīvību gadījumos, ja darbinieks rīkojas / uzvedas pretēji labiem tikumiem ārpus darba laika vai pārtraukuma brīdī. Tādēl nepieciešams no Darba likuma 101. panta pirmās dal̦as 3. punkta svītrot vārdus "veicot darbu" un izteikt punktu šādā redakcijā: "[..] darbinieks rīkojies pretēji labiem tikumiem, un šāda rīcỉba nav savienojama ar darba tiesisko attiecību turpināšanu."

5. Lai novērstu strīdus par reibuma esamību, darba devējam darba līgumā vai uzñēmuma iekšējos normatīvajos aktos jāietver nosacijums par obligātu pienākumu veikt reibuma pakāpes pārbaudi, ja darba devējam rodas aizdomas par atrašanos darba vietā reibuma stāvoklī. Šā pienākuma neievērošana darba devējam dotu pamatu likuma ietvaros izbeigt darba tiesiskās attiecības ar šo darbinieku. Papildu minētajam, nepieciešams izstrādāt arī pārbaudes veikšanas kārtību. Savukārt atrašanās reibumā stāvoklis būtu jākonstatē ar Civilprocesa likumā paredzētajiem pierādīšanas līdzekḷiem. Tādēḷ nepieciešams Darba likuma 101. panta pirmās dal̦as 4. punktu izteikt šādā redakcijā: "[..] darbinieks, veicot darbu, ir alkohola, narkotisko vai toksisko vielu ietekmē. Šos apstākḷus darba devējs pierāda ar Civilprocesa likumā paredzētajiem pierādīšanas līdzekḷiem."

6. Lai darba devējs varētu nepiel̦aut darbinieka atrašanos alkohola, narkotiku vai toksisku vielu ietekmē vai reibumā, ierodoties darbvietā vai veicot darba pienākumus ārpus noteiktās darba vietas, piemēram, izbraucot uz kādu objektu, kā arī darba devējam būtu tiesiski vieglāk uzteikt darbiniekam darba tiesiskās attiecības un pielāgot Darba likuma normas citiem normatīvajiem aktiem, nepieciešams izteikt Darba likuma 101. panta pirmās dal̦as 4. punktu šādā redakcijā: "[..] darbinieks, veicot darbu, ir alkohola, narkotiku vai toksisku vielu ietekmē vai reibumā”. 


\section{Problems of Termination of Legal Work Relationship on the Basis of Labor Law Section 101, Paragraph 1, Clauses 3, 4}

\section{Abstract}

According to Constitution Clause 106 (Satversme) of the Republic of Latvia, it is provided that each person has the right to choose occupation and workplace according to skills and qualification. Forced labour is prohibited. Participation in liquidation of disaster action and employment on the Court's decision is not considered to be forced employment.

Legal regulations of termination of labour relationship are considered in the article, as well as employer's decision on the termination of labour relationship. Such cases are often claimed in the Court and the Informative Statistics proves it, for example, 68 cases were claimed in the Court until the $25^{\text {th }}$ October 2016, where the resumption of work was claimed and in 2015, there were 88 claims. In author's opinion, these data show the range of problems in the Labour Law of Latvia, precisely, in legal regulations of employment relationship. The author thinks that Court Informative Statistics does not disclose the content of claims, and therefore this fact allows investigating termination of employment relationship because the employee had acted against good virtues or the employer had been under influence of alcohol, drug, toxic intoxication, consequently such offences do not allow continuing labour relationship.

The aim of the article is to state the main problems concerning termination of labour relationship, defined in the Labour Law Section 101 Paragraph 1, Clauses 3 and 4 and make proposals to avoid the problems.

Materials and methods are the following: legal acts, analysis of Court practice and scientific literature and description. The results are evaluated, using a descriptive, analytical, logical, inductive and deductive method, but grammar, systematic and teleological method was used to interpret legal norms.

Keywords: labor relationship, termination of employment, labor disputes, Labor Law.

\section{Literatūra}

1. Administratīvā pārkāpuma kodekss: Latvijas Republikas likums: pieṇemts 07.12.1984. un stājas spēkā 01.07.1985. Ziṇotājs. 51, 20.12.1984. Iegūts no: http://likumi.lv/doc.php?id=89648 [sk. 25.11.2016.].

2. Alkohola, narkotisko, psihotropo vai toksisko vielu ietekmes pārbaudes kārtība. LR Ministru kabineta 02.06.2008. noteikumi Nr. 394. Latvijas Vēstnesis. 88, 06.06.2008. Iegūts no: http:// likumi.lv/doc.php?id=176425 [sk. 24.10.2016.]. 
Dace Tarasova. Darba tiesisko attiecību izbeigšanas problemātika

Darba likuma 101. panta pirmās daḷas 3. un 4. punktā noteiktajos gadijumos

3. Augstākās tiesas tiesu prakses apkopojums: Jautājumi par Darba likuma normu piemērošanu. Latvijas Republikas Augstākā tiesa, 2005, 15.

4. Bite, K. Alkohola reibums kā uzteikuma iemesls darba un dienesta tiesiskajās attiecībās. Administratìvā un Kriminālā Justìcija. 2016, 1/2(74/75), 64.

5. Darba likums: Latvijas Republikas likums pieṇemts 20.06.2001. un stājas spēkā 01.06.2002. Latvijas Vēstnesis. 105(2492), 06.07.2001. Iegūts no: http://likumi.lv/doc.php?id=26019 [sk. 24.10.2016.].

6. Darbs. Tēzaurs: Mākslīgā intelekta laboratorija, 2009-2017. Iegūts no: http://www.tezaurs. $\mathrm{lv/ \# /sv/darbs} \mathrm{[sk.} \mathrm{25.10.2016.].}$

7. Iekšlietu ministrijas sistēmas iestāžu un Ieslodzỉjuma vietu pārvaldes amatpersonu ar speciālajām dienesta pakāpēm dienesta gaitas likums: Latvijas Republikas likums pieṇemts 15.06.2006. un stājas spēkā 01.10.2016. Latvijas Vēstnesis. 101(3469), 30.06.2006. Iegūts no: http://likumi.lv/doc.php?id=138750 [sk. 26.10.2016.].

8. Jonāne, J. T. Alkohola reibumā, darba pienākumus veicot. Latvijas Vēstneša portāls. Iegūts no: http://www.lvportals.lv/visi/likumi-prakse/197840-alkohola-reibuma-darba-pienakumusveicot/ [sk. 24.10.2016.].

9. Kalniņš, E. Par jaunā Darba likuma spēkā stāšanos. Jurista Vārds. 2002, 13, 1-3.

10. Krimināllikums: Latvijas Republikas likums pieṇemts 17.06.1998. un stājas spēkā 01.04.1999. Latvijas Vēstnesis. 199/200(1260/1261), 08.07.1998. Iegūts no: http://likumi.lv/doc.php?id= 88966 [sk. 26.10.2016.].

11. Latvijas Republikas Satversme: LV likums: pieṇemta Satversmes sapulcē 15.02.1922. un stājas spēkā 07.11.1922. Latvijas Vēstnesis. 43, 01.07.1993. Iegūts no: http://likumi.lv/doc. php?id=57980 [sk. 24.10.2016.].

12. Latvijas Republikas Augstākās tiesas Senāta Civillietu departamenta 2010. gada 27. oktobra spriedums Civillietā Nr. SKC-928/2010. No: Latvijas Republikas Augstākā tiesa. Tiesu prakse lietās par individuālajiem darba strīdiem. 2010/2011. Iegūts no: http://at.gov.lv/files/uploads/ files/docs/petijumi/darba\%20stridi.pdf

13. Latvian Oxford Living Dictionaries. Iegūts no: https://lv.oxforddictionaries.com/skaidrojums/ darbs [sk. 25.10.2016.].

14. Mel̦kisis, E. Tiesību normu iztulkošana. Likums un Tiesības. 2000, 9.

15. Slicāne, E. Labi tikumi un to nozīme darījumu tiesiskajās attiecībās. Jurista Vārds. 2005, 15(370). Iegūts no: http://www.juristavards.lv/doc/106661-labi-tikumi-un-to-nozime-darijumu-tiesiskajas-attiecibas/ [sk.24.10.2016.].

16. Tiesu informācijas sistēmas. Iegūts no: https://tis.ta.gov.lv/tisreal?Form=TIS_STAT_O [sk. 24.10.2016.].

17. Torgāns, K. Civillikuma komentāri. Rīga: Mans īpašums, 1998, 31.

18. Ventspils tiesas 2014. gada 29. janvāra spriedums civillietā Nr. C40141313. Iegūts no: q=18.+ Ventspils+tiesas+2014.+gada+29.+janv\% C4\% 81ra+spriedums + civilliet\%C4\% 81+Nr.+ $\mathrm{C} 40141313 \&$ oq $=18 .+$ Ventspils + tiesas $+2014 .+$ gada $+29 .+$ janv $\%$ C4\% $81 \mathrm{ra}+$ spriedums + civil liet $\% C 4 \% 81+N r .+C 40141313 \&$ aqs $=$ chrome. .69i57.674j0j4\&sourceid $=$ chrome $\& i e=U T F-8$ [sk. 27.10.2016.]. 